\title{
TINJAUAN TRANSPORTASI PADA KAWASAN KOMERSIL (STUDI KASUS JALAN CIHAMPELAS KOTA BANDUNG)
}

\author{
Amiruddin Akbar Fisu ${ }^{1)}$ Dwiana Novianti Tufail ${ }^{2)}$ Procyoniana S.B. ${ }^{3)}$ Rangga Muh. Nugraha \\ 1) Universitas Andi Djemma, Palopo \\ 2) Institut Teknologi Kalimantan \\ ${ }^{3)}$ Kementerian Perhubungan Republik Indonesia \\ 1) amiruddinakbarfisu07@gmail.com \\ 2)dwianatufail@itk.ac.id
}

\begin{abstract}
Abstrak
Pusat komersil yang terkenal di Kota Bandung antara lain Bandung Electronic City (BEC), Bandung Indah Plaza (BIP), Paris Van Java, Riau Junction, Cihampelas Walk dan lain-lain. Jika melihat guna lahan Kota Bandung, sarana komersil ada yang terpusat, adapula yang membujur membentuk suatu cluster komersil. Oleh karenanya, pertumbuhan sarana komersil di Kota Bandung sangat memengaruhi pola pergerakan di kota ini, juga sangat berkontribusi dalam menciptakan kondisi bertransportasi di Kota Bandung. Titik-titik sarana komersil ini menciptakan tarikan yang besar dan bisa meningkat secara drastis pada waktu-waktu puncak seperti saat akhir pekan dan hari libur. Pada observasi lapangan terlihat, bahwa jumlah permintaan pergerakan orang menuju pusatpusat komersil tersebut seringkali tidak memenuhi kapasitas yang ada. Baik kapasitas jalan, begitupula kapasitas parkir sarana yang bersangkutan. Jebolnya kapasitas jalan menimbulkan kemacetan yang berkepanjangan, dan bertumbuhnya lahan parkir illegal turut ambil peran dalam terjadinya kemacetan di sekitar sarana komersil. Fenomena ini perlu digali agar ditemukan kiranya apa yang menyebabkan hingga terjadi persoalan transportasi yang disebabkan oleh keberadaan sarana komersil. Untuk mendapatkan rona awal mengenai pengaruh keberadaan sarana komersil terhadap permasalahan transportasi di sekitarnya, diambil studi kasus yaitu Shopping Street di jalan Cihampelas.
\end{abstract}

Kata kunci: Transportasi, Hambatan Samping, Jalan Cihampelas, Kawasan Komersil

\section{PENDAHULUAN}

Melihat potensi Bandung sebagai obyek tujuan wisata tentu merupakan keuntungan tersendiri bagi kota Bandung. Keuntungan-keuntungan tersebut antara lain dapat menstimulasi pertumbuhan ekonomi daerah setempat, menambah pendapatan asli daerah, membuka lapangan pekerjaan dan menunjang gerak pembangunan daerah. Selain itu sebagai sarana mengenalkan kebudayaan asli daerah sehingga Indonesia pada umumnya dan kota Bandung pada khususnya lebih dikenal dan menjadi tempat persinggahan para wisatawan.

Potensi wisata yang menjadi daya tarik terbesar di Kota Bandung yaitu wisata kuliner dan wisata belanja. Bandung adalah kota yang berhasil mengembangkan industri fashion. Bukti nyata atas perkembangan pesat industri fashion di kota Bandung adalah pesatnya pertumbuhan FO (factory outlet) dan Distro (distribution store) sebagai agen distribusi produk tekstil yang mengandalkan kreatifitas. Industri kreatif fashion sudah menjadi icon kota Banudng. Kekuatan utama industri kreatif adalah desain, keragaman bahan baku, kekhususan merek, dan keunikan produk. Keberhasilan creative fashion di Bandung tidak terlepas dari keberadaan industri tekstil dan keunikan pendistribusiannya yaitu FO dan Distro. Wisata belanja merupakan pilihan yang menarik karena disamping para pengunjung membeli barang belanjaan pengunjung juga dapat sekaligus menikmati suguhan suasana yang nyaman dan menyenangkan.

Potensi wisata belanja di Kota Bandung menjadi pendongkrak datangnya wisatawan baik domestik maupun internasional ke kota ini. Dengan demikian, Kota Bandung pun menjadi kota yang dibanjiri dengan sarana komersil (komersil). Aktivitas perdagangan terpusat di jantung Kota Bandung, namun ada pula yang tersebar secara acak, menyusur di beberapa ruas jalan. Pusat komersil yang terkenal di Kota Bandung antara lain Bandung Electronic City (BEC), Bandung Indah Plaza (BIP), Paris Van Java, Riau Junction, Cihampelas Walk dan lain- 
lain. Jika melihat guna lahan Kota Bandung, sarana komersil ada yang terpusat, adapula yang membujur membentuk suatu cluster komersil. Oleh karenanya, pertumbuhan sarana komersil di Kota Bandung sangat memengaruhi pola pergerakan di kota ini, juga sangat berkontribusi dalam menciptakan kondisi bertransportasi di Kota Bandung. Titik-titik sarana komersil ini menciptakan tarikan yang besar dan bisa meningkat secara drastis pada waktu-waktu puncak seperti saat akhir pekan dan hari libur. Pada observasi lapangan terlihat, bahwa jumlah permintaan pergerakan orang menuju pusat-pusat komersil tersebut seringkali tidak memenuhi kapasitas yang ada. Baik kapasitas jalan, begitupula kapasitas parkir sarana yang bersangkutan. Jebolnya kapasitas jalan menimbulkan kemacetan yang berkepanjangan, dan bertumbuhnya lahan parkir illegal turut ambil peran dalam terjadinya kemacetan di sekitar sarana komersil.

Fenomena ini perlu digali agar ditemukan kiranya apa yang menyebabkan hingga terjadi persoalan transportasi yang disebabkan oleh keberadaan sarana komersil. Untuk mendapatkan rona awal mengenai pengaruh keberadaan sarana komersil terhadap permasalahan transportasi di sekitarnya, diambil studi kasus yaitu Shopping Street di jalan Cihampelas.

\section{METODE}

Jenis penelitian ini adalah penelitian deskriptif-evaluatif, dengan pendekatan kualitatif. Penelitian deskriptif dapat diartikan sebagai proses pemecahan masalah yang dianalisa dengan menggambarkan keadaan obyek penelitian pada saat ini berdasarkan fakta-fakta yang nampak atau kondisi eksisting (Fisu, 2016). Pelaksanaan metode penelitian deskriptif tidak terbatas sampai pada pengumpulan dan penyusunan data, tetapi meliputi analisis untuk mengetahui penyebab permasalahan (Fisu, 2018). Metode ini yang kemudian akan digunakan untuk mengetahui permasalahan transportasi pada Jalan Cihampelas.

\section{HASIL DAN PEMBAHASIAN Gambaran Umum Jalan Cihampelas}

Pada awalnya, koridor Jalan Cihampelas merupakan kawasan perumahan. Kegiatan ekonomi, khususnya perdagangan, hanya berskala lingkungan berupa toko barang kebutuhan sehari-hari disamping kegiatan jasa lain seperti bengkel, sekolah dan perkantoran. Kawasan perumahan di sepanjang Jalan Cihampelas semula berkesan asri seperti kawasan perumahan di sepanjang jalan Cipaganti. Namun kemudian mulai muncul kegiatan baru berupa kegiatan komersil. Ruas Jalan Cihampelas yang strategis mulai ditempati oleh kegiatan perdagangan jeans. Sementara itu, kegiatan jasa lainnya serta perumahan menempati kedua ruas ujung jalan. Lebih jauh lagi, kegiatan perdagangan jeans ini semakin menggeser penggunaan lahan yang semula perumahan. Gejala ini memang sulit dihindarkan, terlebih pada kota yang kekurangan lahan kegiatan komersil untuk memenuhi perkembangan kegiatan kota.

Saat ini, shopping street Jalan Cihampelas merupakan koridor jalan dengan dominasi aktivitasnya adalah sebagai pusat perdagangan jeans. Tidak lepas dari julukan Bandung sebagai kota mode, jeans menjadi pilihan strategis karena jeans beaneka ragam macamnya dan disukai oleh hampir semua lapisan usia karena fasionable dan simple. Disamping itu kota Bandung sendiri banyak terdapat industri textil khususnya jeans sehingga Cihampelas dapat menjadi ajang promosi bagi dunia luar.Jalan Cihampelas merupakan jalan kolektor sekunder yang menghubungkan bagian utara dan pusat Kota Bandung. Lokasi kawasan yang strategis serta tingginya intensitas kegiatan perdagangan dan jasa menjadikan kawasan ini sebagai salah satu pusat kegiatan ekonomi di Kota Bandung. Perkembangan kawasan Jalan Cihampelas sebagai salah satu pusat perdagangan dan jasa di Kota Bandung menimbulkan tarikan yang besar dan mengakibatkan peningkatan volume kendaraan di ruas Jalan Cihampelas ini. 
Menurut RTRW Kota Bandung 2013, kawasan perdagangan adalah lokasi yang ditetapkan untuk transaksi langsung antara pembeli dan pedagang. Wadah fisik dari kegiatan transaksi ini antara lain berupa pertokoan, pasar atau pusat belanja. Sedangkan kawasan jasa adalah lokasi yang ditetapkan untuk menyelenggarakan berbagai kegiatan pelayanan dengan wadah fisiknya berupa perkantoran dengan kegiatan ekonomi atau serangkaian kegiatan yang umumnya tidak kasat mata, dan tidak berdampak kepada kepemilikan apapun, yang ditawarkan satu pihak kepada orang lain, yang produknya dinikmati pada saat diproduksi, serta mempunyai nilai tambah dalam berbagai bentuk ( kenyamanan, hiburan, kemudahan atau kesehatan).

Arahan pengembagan kawasan dan kegiatan perdagangan dan jasa berdasarkan RTRW Kota Bandung 2013, antara lain adalah merevitalisasi atau meremajakan kawasan pasar yang tidak tertata dan/atau menurun kualitas pelayanannya dengan tanpa mengubah kelas dan/atau skala pelayanannya yang telah ditetapkan. Kebijakan lainnya yaitu mengendalikan kegiatan perdagangan dan mengarahkan perkembangannya ke lokasi yang sesuai dengan peruntukannya. Sedangkan untuk kegiatn jasa, arahan pengembangannya antara lain yaitu mewajibkan penyediaan parkir dan prasarana yang memadai bagi pengembangan kegiatan jasa.

\section{Kondisi Tata Guna Lahan}

Penataan Ruang dan sistem transportasi memiliki integritas (keterkaitan) yang erat dalam pembentukan suatu ruang (Katiandagho, Ngangi \& Kaunang, 2017). Kegiatan pembangunan dan pengembangan infrastruktur perlu pengkajian mendalam dari berbagai sisi, termasuk aspek daya dukung lahan dan aspek tata ruang (Fisu, 2019). Di sisi lain pertumbuhan aktivitas ekonomi akan mempengaruhi permintaan terhadap transportasi yang lebih banyak (Fisu, 2019), pembangunan atau pengembangan sarana transportasi juga dapat menimbulkan dampak positif terhadap suatu wilayah (Fisu, 2018). Kegiatan transportasi harus dilakukan secara menyeluruh dengan keterpaduan fisik antar moda berupa titik simpul pertemuan antar moda (Humang, 2016).

Daerah sepanjang Jalan Cihampelas yang berfungsi sebagai jalan kolektor sekunder merupakan suatu kawasan yang termasuk ke dalam Wilayah Pengembangan Cibeunying. Secara administrative, wilayah studi observasi ini termasuk ke dalam Kelurahan Cipaganti, Kecamatan Coblong. Sedangkan secara fisik geografis, Jalan Cihampelas dimulai dari persimpangan Jl. Dr. Setiabudi dan Jl. Ciumbeuluit di sebelah utara, sampai ke persimpangan Jl. Pajajaran dan Jl. Cicendo. Dari keseluruhan Jalan Cihampelas, untuk pengamatan ini dibatasi wilayah studi yaitu mulai dari persimpangan Cihampelas-Setiabudi-Ciumbeuluit, sampai persimpangan Cihampelas-Pasteur.

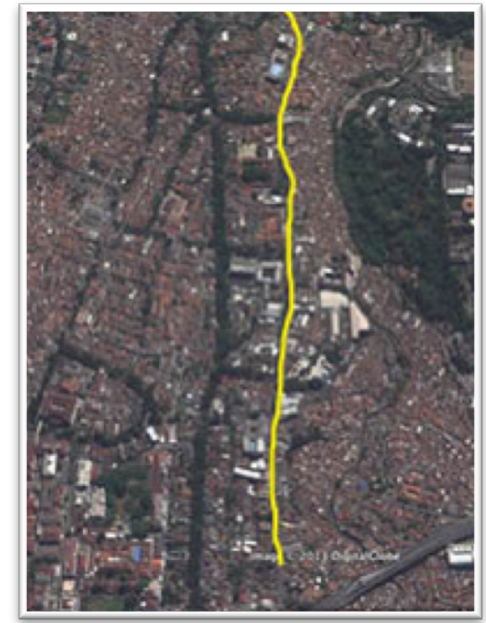

Gambar 1: Ruas Jalan Cihampelas Sebagai Objek Pengamatan Sumber: Google earth 
Ruas jalan Cihampelas yang menjadi wilayah observasi memiliki panjang $\pm 1,7 \mathrm{~km}$. Sepanjang jalan ini tidak hanya terdapat sarana komersil. Penggunaan lahan di wilayah ini berupa perkantoran, pendidikan, rumah sakit, hotel, perdagangan dan pusat perbelanjaan (mall). Jalan Cihampelas memiliki lebar 9 meter, dengan dua lajur dan satu arah.
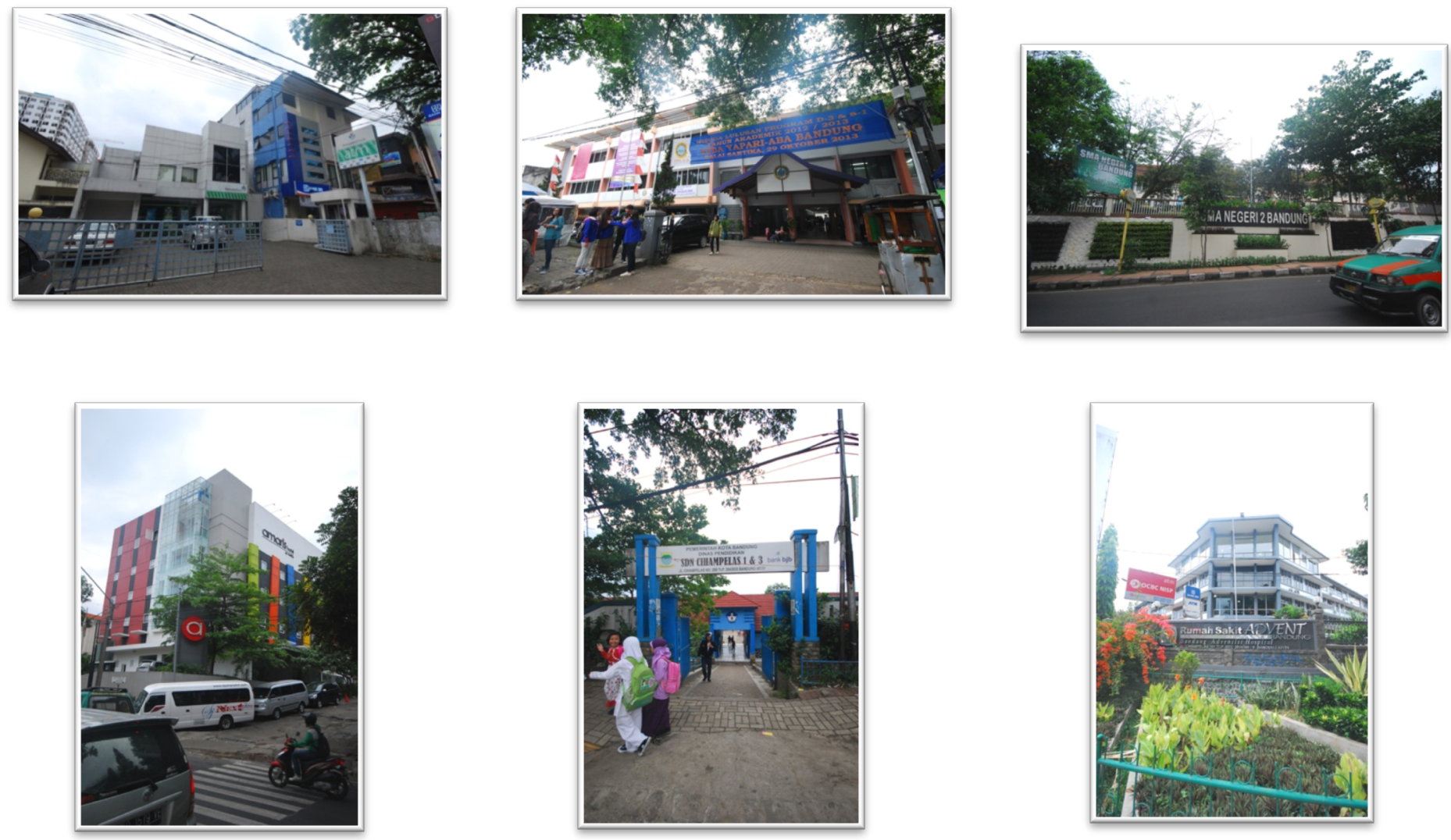

Gambar 2: Berbagai aktifitas nonkomersil di Jl. Cihampelas : 1. Bank, 2. Kampus STBA, 3. SMAN 2, 4. Hotel Amaris, 5. SD Cihampelas, 6. RS Advent

\section{Kondisi Pergerakan}

Transportasi sangat terkait dengan aksesibilitas, dimana aksesibilitas merupakan faktor yang sangat menentukan organisasi ruang di kawasan perkotaan. Peningkatan aksesibilitas dan penggunaan lahan adalah proses yang saling terkait. Sebaran guna lahan seperti perumahan, industry, dan komeril menentukan lokasi kegiatan penduduk (Aditiyananta, 2014). Sebagai akibat dari pertumbuhan penduduk yang disertai dengan meningkatnya perekonomian, maka tingkat mobilitas baik orang maupun barang akan meningkat pula (Hukmia, 2015).

Jalan Cihampelas merupakan jalan satu arah dengan dua lajur tak terbagi dengan proporsi jalur yang sama (50-50). Median jalan berupa marka garis putus-putus. Kelengkapan jalan yang ada meliputi rambu dilarang berhenti, papan penunjuk arah jalan, area penyebrangan (zebra cross), rambu forbidden, lampe pengatur lalu lintas dan lampu jalan. 
Jalan Cihampelas memiliki lebar jalan rata-rata $7 \mathrm{~m}$, dengan lebar efektif jalan rata-rata $6 \mathrm{~m}$. Pada ruas jalan ini, lebar bahu jalan sefektif rata-rata di bawah $0,5 \mathrm{~m}$. Di Jalan Cihampelas, terdapat fasilitas trotoar yang juga sebagai jalur pejalan kaki dengan lebar $1 \mathrm{~m}$. Ukuran ini Jalur pejalan kaki ini hanya terdapat pada sebagian ruas jalan. Setalah Cihampelas Walk Mal, lebar jalan yang ada yaitu $8 \mathrm{~m}$, dengan lebar efektif rata-rata 7 meter. Trotoar yang ada memiliki lebar rata-rata $1,5 \mathrm{~m}$, dan lebar bahu jalan efektif rata-rata $0,5 \mathrm{~m}$. Sempadan bangunan dan sempadan jalan tidak lagi layak kondisinya. Area tersebut dijadikan lahan berjualan oleh pedagang kaki lima dan kios-kios pinggir jalan. Pada sebagian ruas jalan yang lain, sempadan bangunan ada pula yang difungsikan sebagai lahan parkir.

Aktivitas komersial adalah kegiatan pertukaran atau jual/beli barang dan jasa untuk mendapatkan keuntungan dengan cara perdagangan dan seluruh kegiatan pendukungnya seperti transportasi, komunikasi, perbankan, dan sebagainya (Wardhana \& Haryanto, 2016). Saranasarana seperti sarana komersil, kesehatan (rumah sakit), pendidikan, hotel dan restoran menciptakan potensi tarikan menuju ruas Jalan Cihampelas. Dengan demikian, tidak hanya tarikan menuju sarana komersil yang menciptakan pergerakan di ruas jalan ini.

Jam-jam puncak yang berlaku di ruas jalan ini yaitu berdasarkan waktu libur, misalnya ketika akhir pekan, karena ruas jalan ini didominasi oleh sarana komersil yang menjadi daya tarik bagi wisatawan. Pada hari kerja, waktu puncak pergerakan terjadi pada malam dan sore hari.

Pergerakan di ruas Jalan Cihampelas dilalui oleh beberapa jenis moda angkutan. Modamoda tersebut antara lain mobil pribadi, sepeda motor, bus pariwisata, shuttle bus. Pergerakan orang di ruas jalan ini juga tidak dapat dinafikkan kontribusinya dalam mengisi pergerakan di ruas jalan ini. Pergerakan pejalan kaki menjadi perlu diperhatikan karena lahan bagi pejalan kaki di jalur pejalan kaki dan sempadan bangunan telah diambil alih oleh pedagang kaki lima, akibatnya pergerakan pejalan kaki dilakukan dengan menggunakan area bahu jalan. Ramainya pergerakan juga mempengaruhi tingkat keamanan bagi pejalan kaki.

Tingginya volume pergerakan yang melalui jalan ini, yang hanya memiliki lebar $9 \mathrm{~m}$. Oleh karenanya pergerakan yang terjadi tidak dapat diimbangi oleh jaringan jalan yang ada, sehingga mengakibatkan ketidakseimbangan antara supply dengan demand terhadap transportasi. Pada akhirnya menimbulkan permasalahan transportasi yaitu berupa kemacetan lalu lintas.

\section{Identifikasi masalah dan Analisis Deskriptif}

Berdasarkan observasi awal yang telah dilakukan, maka permasalahan transportasi yang terjadi di Jalan Cihampelas, antara lain:

1. Tidak sesuainya aktivitas pergerakan yang ditampung oleh Jalan Cihampelas.

Jika melihat karakteristik fisik Jalan Cihampelas, yang memiliki lebar jalan kurang lebih 9 meter, dan menjadi akses menuju jalan arteri yaitu jalan Pasteur dan jl. Pasupati, maka dapat dinilai bahwa Jalan Cihampelas termasuk jalan arteri sekunder. Kriteria untuk jalan kelas ini, salah satunya yaitu kapasitas lebih besar dari volume lalu lintas rata-rata dan kecepatan rencana min $60 \mathrm{~km} / \mathrm{jam}$. Banyaknya titik yang berpotensi menjadi tarikan di Jalan Cihampelas, menyebabkan kapasitas jalan ini tidak mampu menampung volume pergerakan yang ada. Meningkatnya volume pergerakan yang melebihi kapasitas yaitu berkumpulnya sarana-sarana komersil di ruas Jalan Cihampelas. Pertumbuhan sarana ini juga diiringi oleh pertumbuhan pedagang kaki lima di wilayah sempadan jalan, sehingga justru mengurangi kapasitas jalan ini.

2. Banyaknya jenis moda angkutan yang melintasi Jalan Cihampelas.

Kemacetan yang terjadi merupakan efek klimaks dari akumulasi persoalan pergerakan yang terjadi di jalan Cihampelas. Ruas jalan Cihampelas yang telah mengakomodasi aktifitas 
wisatawan, seperti berbelanja, wisata kuliner dan penginapan, menyebabkan jalan Cihampelas dilalui oleh bus pariwisata. Kelas jalannya sebagai jalan arteri sekunder yang menghubungkan jalan lokal ke jalan arteri juga menyebabkan jalan ini dilalui pula oleh angkutan umum. Selain itu volume kendaraan pribadi, baik yang singgah maupun yang hanya lewat juga tak bisa dinafikkan, dari hari ke hari volumenya semakin bertambah. Dengan demikian, hal ini menyebabkan semakin tingginya volume pergerakan di sepanjang Cihampelas. Lebar jalan yang relatif sempit dan jumlah kendaraan yang lewat semakin bertambah adalah faktor yang memicu terjadinya kemacetan.

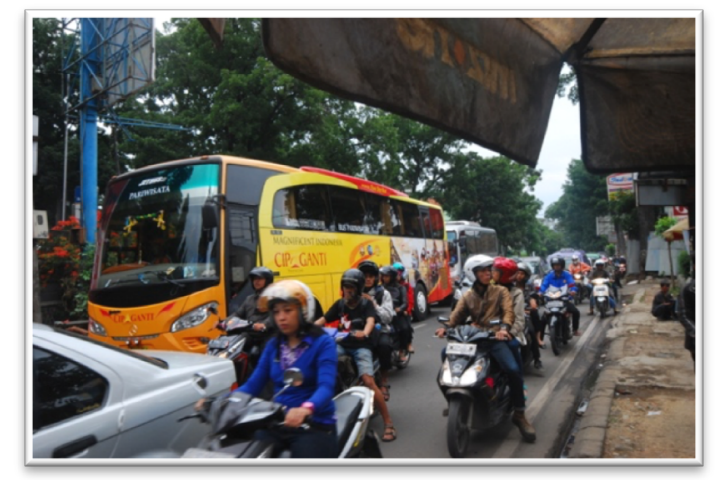

Gambar 3: Beragam moda berbaur di Jalan Cihampelas

3. Menyempitnya DAMIJA Jalan Cihampelas.

Keberadaan sarana-sarana komersil yang bertumbuh di Jalan Cihampelas dibarengi juga dengan pertumbuhan Pedagang Kaki Lima dan pedagang asongan yang berjualan di sempadan jalan. Hal ini menyebabkan jalur pejalan kaki dan sempadan yang ada tidak bisa dimanfaatkan bagi para pejalan kaki maupun sebagai lahan parkir. Keberadaan PKL ini juga sedikit banyak mengambil daerah bahu jalan, sehingga pejalan kaki yang ingin melintas di Jalan Cihampelas juga harus menggunakan bahu jalan. Hal inilah yang kemudian juga menjadi faktor yang meningkatkan hambatan samping.Hambatan samping ini menyebabkan kendaraan berjalan melambat di ruas Jalan Cihampelas, dan menjadikan Jalan Cihampelas semakin menurun kualitas pelayanannya.

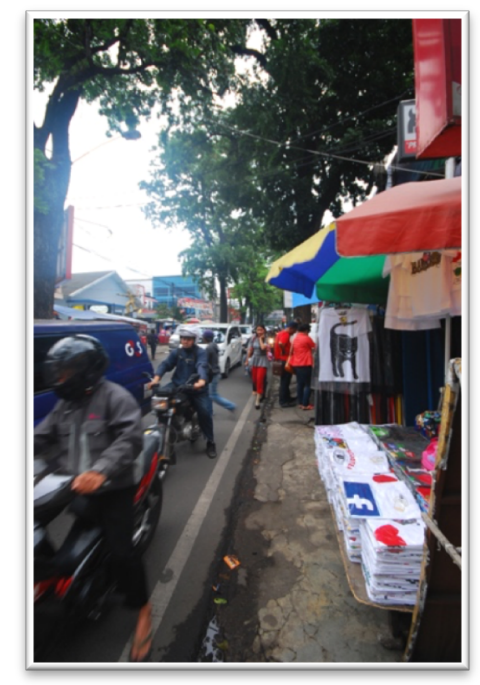

Gambar 4: Kurangnya pedestrian dan keberadaan PKL di pinggir jalan menyulitka para pejalan kaki 
Adanya Cihampelas Walk Mall juga menambah jumlah tarikan menuju jalan ini. di titik ini terjadi Bottle Neck Syndrom, yaitu menumpuknya volume kendaraan di sekitar Cihampelas Walk Mall, dan setelahnya lalu lintas kendaraan kembali lancar. Jalan Cihampelas yang kini menjelma menjadi shopping street, justru tidak mengakomodasi kebutuhan keamanan dan kenyamanan bagi para pejalan kaki. Apalagi ditambah dengan banyaknya kendaraan pengunjung yang diparkirkan di bahu-bahu jalan.

Keberadaan Angkutan Kota juga menambah kemacetan yang terjadi di Jalan Cihampelas. Angkot yang berhenti seenaknya, manciptakan ketidaklancaran pergerakan di ruas jalan ini, terutama yang berhenti di depan Ciwalk Mall.

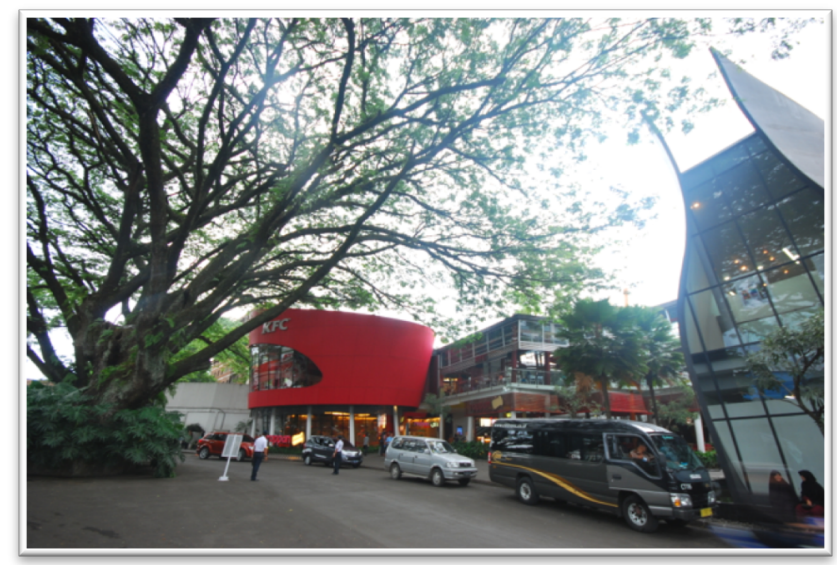

Keberadaan Cihampelas Walk Mal menjadi salah satu penyebab penumpukan kendaraan di Jl. Cihampelas

4. Bertumbuhnya lahan parkir on street.

Permasalahan lain adalah parkir. Banyaknya aktifitas yang membutuhkan lahan parkir di Jalan Cihampelas tidak dibarengi dengan ketersediaan parkir yang memadai. Beberapa FO dan Distro menyediakan tempat parkir yang sempit dan beberapa lagi bahkan tidak menyediakan tempat parkir sama sekali. Hal ini berimbas terhadap jalan-jalan kecil di sekitar Jalan Cihampelas yang kemudian dijadikan tempat parkir badan jalan (on street parking).

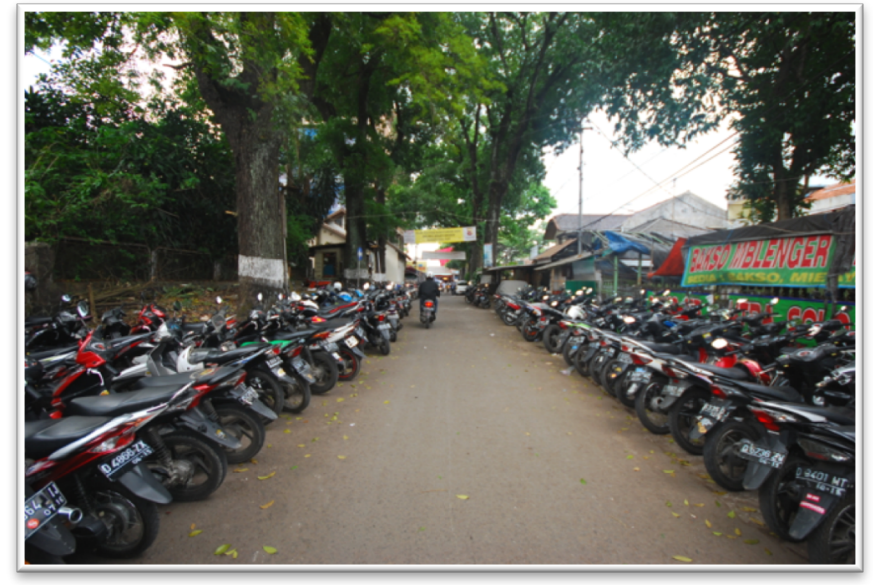

Gambar 5: Parkir badan jalan karena kurangnya lahan parkir di sekitar Jalan Cihampelas

Berdasarkan hasil pengamatan awal yang dilakukan, maka inti dari permasalahan yang terjadi yaitu tingkat pelayanan Jalan Cihampelas telah mengalami penurunan. Penurunan tingkat pelayanan jalan ini diakibatkan oleh kapasitas Jalan Cihampelas yang tidak mampu menampung volume pergerakan yang ada. Selain itu banyaknya hambatan samping yang timbul akibat dari adanya aktivitas yang berlangsung di sepanjang Jalan Cihampelas juga 
mengakibatkan penurunan kapasitas jalan sehingga mempengaruhi tingkat pelayanan jalan. Dengan kondisi seperti ini, maka seringkali kemacetan terjadi di Jalan Cihampelas terutama pada jam-jam sibuk.

Kemacetan yang terjadi di jalan Cihampelas hadir sebagai akumulasi persoalan transportasi yang timbul sebagai akibat dari tidak direncanakannnya kawasan tersebut secara matang dari kawasan pemukiman berubah menjadi kawasan perdagangan tanpa melihat potensi dan permasalahan yang ditimbulkannya.

Secara garis besar, permasalah di Jalan Cihampelas dapat dibagi menjadi dua, yaitu masalah yang disebabkan oleh faktor internal, dalam hal ini adalah hambatan samping, dan masalah yang disebabkan oleh faktor eksternal, yaitu jumlah tarikan atau pengunjung dan jumlah pelintas, baik itu kendaraan maupun pejalan kaki.

\section{Faktor Internal (Hambatan Samping di Jalan Cihampelas)}

Fenomena hambatan samping di jalan cihampelas perlu untuk diidentifikasi guna memperoleh gambaran factual mengenai pengaruhnya bagi kemacetan atau menurunnya kinerja jalan. Indikasi yang muncul adalah hambatan samping turut berperan dalam mengakibatkan kemacetan di Jalan Cihampelas. Bahkan hambatan samping yang terjadi pada ruas Jalan cihampelas menjadi salahsatu factor utama penyebab kemacetan arus lalulintas. Berdasarkan pengamatan di lapangan, hambatan samping di Jalan Cihampelas disebabkan oleh beberapa factor, yaitu:

- Fungsi-fungsi aktifitas di samping jalan akibat penggunaan lahan yang intensif untuk aktifitas-aktifitas perkotaan berupa pemotongan arus lalulintas akibat kendaraan yang keluar masuk dari fungsi-fungsi atau aktifitas-aktifitas tersebut, berhentinya kendaraan pada badan jalan, aktifitas penyeberangan jalan oleh pejalan kaki, dan lainlain.

- Penggunaan badan jalan untuk areal parker kendaraan, dimana sebagian badan jalan digunakan untuk memenuhi kebutuhan parker pengunjung sebagai konsekuensi dari maraknya aktivitas perdagangan dan jasa yang berada di sepanjang ruas jalan Cihampelas yang pada umumnya tidak memiliki tempat parker khusus

- Aktifitas menaikkan atau menurunkan penumpang dan barang di badan jalan, baik itu dari angkutan umum maupun dari kendaraan pribadi.

- Aktivitas pejalan kaki yang tidak memanfaatkan secara optimal fasilitas trotoar akibat penggunaan trotoar untuk pedagang kaki lima (PKL) sehingga ruang untuk pejalan kaki berkurang serta pemanfaatan fasilitas penyeberangan yang tidak efisien dan berimbas pada penggunaan badan jalan untuk berjalan kaki.

- Aktifitas pedagang kaki lima (PKL) di sepanjang ruas jalan Cihampelas, dimana konsentrasi terbesar berada disekitar Ciwalk.

2. Faktor Eksternal (Jumlah tarikan/pengunjung dan pelintas yang besar)

Tumbuhnya aktifitas-aktifitas komersil mengakibatkan besarnya tarikan, jumlah pengunjung dan pelintas di Jalan Cihampelas. Volume lalu lintas yang tinggi terjadi akibat penumpukan arus lokal, regional dan arus menerus serta bercampurnya moda transportasi, baik modern maupun tradisional.

Kedua faktor di atas bersifat multikausal atau saling mempengaruhi satu dengan yang lainnya. Sehingga, dalam pembahasan kali ini, kedua faktor tersebut tidak dapat dipisahkan.

Bangkitan pergerakan merupakan fungsi yang berkorelasi positif dengan perubahan guna lahan suatu wilayah atau kawasan. Bangkitan pergerakan di sisi Jalan Cihampelas dipengaruhi oleh karakteristik guna lahan juga aktivitas perkotaan yang melekat. Dari sub pembahasan di atas, dapat dirumuskan hubungan antara keduanya dengan potensi bangkitan pergerakan yang ditimbulkan. 
Tabel 1. Potensi Bangkitan Pergerakan di Jalan Cihampelas

\begin{tabular}{|c|c|c|}
\hline No. & Aktifitas/fungsi & Deskripsi \\
\hline 1. & Kawasan Ciwalk (Cihampelas Walk) & $\begin{array}{l}\text { Merupakan salah satu titik yang menyebabkan } \\
\text { kemacetan paling parah di Jalan Cihampelas, Di titik } \\
\text { ini terdapat pusat perbelanjaan (mall), travel, hotel, } \\
\text { rumah makan dan restoran, dll. Juga karena } \\
\text { keberadaan Ciwalk, terjadi bottle-neck syndrome, } \\
\text { yaitu penyempitan daerah milik jalan dikeranakan } \\
\text { semakin menumpuknya PKL di sekitar titik ini, dank } \\
\text { arena banyaknya angkutan kota (angkot) yang } \\
\text { berhenti di depan Ciwalk Mal. Aktivitas pergerakan } \\
\text { tertinggi tampak pada jam-jam istirahat siang (13.00- } \\
\text { 15.00) hingga malam (18.00-20.00) }\end{array}$ \\
\hline 2. & $\begin{array}{l}\text { Deretan Pertokoan sekitar Ciwalk } \\
\text { (Factory Outlet \& Distro) }\end{array}$ & $\begin{array}{l}\text { Deretan FO dan distro tersebut juga menjadi tujuan } \\
\text { para pelintas. Tidak tersedianya lahan parkir untuk } \\
\text { pengunjung-pengunjung FO. Selain itu, tidak adanya } \\
\text { sempadan bangunan yang memadai meningkatkan } \\
\text { hambatan samping di ruas jalan ini. }\end{array}$ \\
\hline 3. & PKL (Pedagang Kaki Lima) & $\begin{array}{l}\text { PKL yang terdapat di Jl. Cihampelas memenuhi area } \\
\text { sempadan bangunan. Hal ini menyebabkan } \\
\text { kurangnya lahan parkir untuk pertokoan. PKL yang } \\
\text { memenuhi sempadan, juga menghambat lalu litas } \\
\text { pejalan kaki, sehingga pejalan kaki menggunakan } \\
\text { bahu jalan. }\end{array}$ \\
\hline 4. & Restoran \& Rumah makan & $\begin{array}{l}\text { Keberadaan restoran dan rumah makan tidak begitu } \\
\text { memengaruhi tersendatnya pergerakan di Jalan } \\
\text { Cihampelas. Restoran maupun rumah makan } \\
\text { memiliki sempadan bangunan yang masih } \\
\text { dimanfaatkan sebagai lahan parkir. }\end{array}$ \\
\hline 5. & Hotel & $\begin{array}{l}\text { Hotel- hotel di Jalan Cihampelas memiliki lahan } \\
\text { parkir yang memadai, dan jumlah hotel yang ada juga } \\
\text { tidak memberikan sumbangsih yang besar terhadap } \\
\text { volume pergerakan di Jalan Cihampelas. Hanya saja, } \\
\text { karena keberadaan hotel, Jalan Cihampelas harus } \\
\text { dilalui oleh kendaraan-kendaraan yang cukup besar } \\
\text { yaitu shuttle bus dan bus pariwisata. }\end{array}$ \\
\hline 6. & Perkantoran dan Bank & $\begin{array}{l}\text { Keberadaan sarana perkantoran dan bank tidak } \\
\text { memberikan pengaruh yang berarti dalam pergerakan } \\
\text { yang terjadi di Jalan Cihampelas. }\end{array}$ \\
\hline 7. & Pendidikan (kampus \& Sekolah) & $\begin{array}{l}\text { Pergerakan yang ramai karena titik ini hanya } \\
\text { berlangsung pada jam-jam sibuk sekolah dan hanya } \\
\text { terjadi di sekitar sekolah, tidak berpengaruh secara } \\
\text { luas di Jalan Cihampelas. }\end{array}$ \\
\hline 8 & Kesehatan (Rumah sakit) & $\begin{array}{l}\text { Terdapat satu rumah sakit di jalan Cihampelas, } \\
\text { sehingga pergerakan yang diciptakannya tidak besar. }\end{array}$ \\
\hline
\end{tabular}

Hambatan samping merupakan dampak terhadap kinerja dari aktifitas samping jalan seperti gerakan pejalan kaki, pemberhentian angkutan umum pada ruas jalan, kendaraan masuk dan keluar ruas jalan, kendaraan lambat (sepeda, gerobak, dll), yang menyebabkan penurunan 
kapasitas dan kinerja jalan perkotaan. Hambatan samping Jalan Cihampelas memiliki pengaruh yang signifikan terhadap besar kecilnya kapasitas jalan di kawasan tersebut. Semakin besar hambatan samping semakin kecil kapasitas efektif jalan, begitu juga sebaliknya. Dengan semakin kecilnya kapasitas jalan akan menyebabkan kinerja/ tingkat pelayanan jalan menjadi semakin rendah.

Faktor hambatan samping berperan dalam mengakibatkan kemacetan di Ruans jalan cihampelas. Bahkan hambatan samping yang terjadi pada ruang jalan Cihampelas menjadi salah satu faktor utama penyebab kemacetan lalulintas Hambatan samping tersebut disebabkan oleh beberapa faktor:

Tabel 2. Faktor Penyebab Hambatan Samping di Jalan Cihampelas

\begin{tabular}{|c|c|c|}
\hline No. & Penyebab Hambatan & Deskripsi \\
\hline 1. & Aktivitas guna lahan sisi jalan & $\begin{array}{l}\text { Berupa pemotongan arus lalulintas akibat } \\
\text { kendaraan yang keluar masuk dari aktivttas sisi } \\
\text { jalan, berhentinya kendaraan pada badan jalan, } \\
\text { aktivitas penyeberang menuju sisi jalan, dan } \\
\text { melintasnya kendaraan lambat (sepeda, gerobak, } \\
\text { dll) }\end{array}$ \\
\hline 2. & Penggunaan badan jalan untuk parkir kendaraan & $\begin{array}{l}\text { Jalan Cihampelas yang pada umumnya tidak } \\
\text { memiliki tempat parkir khusus yang memadai } \\
\text { untuk tiap aktivitas guna lahannya. Parkir } \\
\text { dilakukan secara on street. }\end{array}$ \\
\hline 3. & $\begin{array}{l}\text { Penggunaan badan jalan untuk aktivitas menaik- } \\
\text { turunkan penumpang dan barang }\end{array}$ & $\begin{array}{l}\text { Berupa pemotongan arus lalulintas akibat } \\
\text { kendaraan melakukan aktivitas menaik-turunkan } \\
\text { penumpang angkutan umum dan barang, serta } \\
\text { kendaraan pribadi. Tidak adanya fasilitas halte } \\
\text { angkutan dan tempat khusus untuk bongkar muat } \\
\text { barang, menjadikan aktivitas tersebut berlangsung } \\
\text { di tepi bahkan hingga di tengah jalan. }\end{array}$ \\
\hline 4. & Aktivitas pejalan kaki dan kaki lima & $\begin{array}{l}\text { Berupa aktivitas pejalan kaki yang tidak dapat } \\
\text { memanfaatkan trotoar atau pedestrian yang } \\
\text { dipenuhi oleh para pedagang kaki lima. Kedekatan } \\
\text { fungsi aktivitas yang menimbulkan bangkitan } \\
\text { pergerakan yang besar menyebabkan jumlah } \\
\text { pejalan kaki di Jalan cihampelas cukup tinggi }\end{array}$ \\
\hline
\end{tabular}

\section{PENUTUP}

\section{Kesimpulan}

Berdasarkan kajian yang dilakukan terhadap hasil temuan di lapangan dan dibandingkan dengan teori yang digunakan, dapat dilihat bahwa kemacetan yang terjadi di Jalan Cihampelas merupakan efek yang terakumulasi dari perkembangan aktivitas yang bertumbuh di ruas jalan ini. perkembangan sarana komersil berupa pertumbuhan pusat perbelanjaan, pertokoan dan PKL mennyebabkan beberapa dampak, antara lain berkurangnya lebar jalan efektif dan juga lebar trotoarnya. Kondisi ini juga turut didukung dengan tidak tersedianya lahan parkir yang memadai kebutuhan parkir dari tarikan akibat sarana komersil 
yang ada. Efek pertama yang terjadi dari kondisi ini, yaitu terjadinya hambatan samping pada ruas jalan Cihampelas. Hambatan samping tersebut berupa pejalan kaki yang menggunakan bahu jalan sebagai lintasannya, kendaraan yang parkir atau berhenti, kendaraan yang keluar masuk dan kendaraan yang berjalan lambat.

Sebagai hasil awal dari observasi ini, dapat ditarik kesimpulan bahwa hambatan samping memberikan kontribusi yang cukup besar terhadap kinerja jalan di wilayah studi ruas Jalan Cihampelas. Dengan demikian, hambatan samping memberikan kontribusi bagi menurunnya tingkat pelayanan Jalan Cihampelas sebagai akibat aktivitas guna lahan di sekitarnya. Dari penyebab yang disimpulkan sementara, dapat dilihat bahwa permasalahan utama dari kemacetan yang terjadi adalah kurangnya fasilitas parkir, tidak disiplinnya aktivitas turun-angkut angkutan kota dan aktivitas pejalan kaki dan PKL. Dengan demikian, rekomendasi yang diajukan adalah untuk mengintervensi keempat hal tersebut.

\section{Rekomendasi}

Berdasarkan hasil pengkajian singkat dari observasi yang telah dilakukan, diajukan beberapa rekomendasi yang bersifat menangani jangka pendek, namun berupaya mengatasi persoalan kemacetan akibat hambatan samping di Jalan Cihampelas. Rekomendasi untuk setiap persoalan utama antara lain:

- Penertiban aktivitas parkir di ruas Jalan Cihampelas. Rekomendasi ini dapat dilaksanakan dengan cara pembangunan gedung parkir khusus untuk kawasan shopping street Cihampelas, agar aktivitas parkir menjadi terpusat dan tidak terlalu memakan lahan. Selain itu dapat juga dilakukan dengan pemasangan tanda "Dilarang Parkir" di titik-titik yang hambatan samping.

- Penertiban angkutan umum, yaitu dengan menentukan titik-titik perhentian bagi angkutan umum, yang telah dilengkapi dengan fasilitas halte yang memadai.

- Penertiban PKL di sempadan jalan, dengan cara membangun pagar pembatas ataupun dengan peremajaan jalur pejalan kaki.

\section{Catatan Studi}

Beberapa kelemahan yang ditemukan selama pengkajian terhadap fenomena yang ditemukan, antara lain:

- Pengkajian ini masih ada pada tataran yang normatif, karena tidak didukung dengan metodologi penelitian yang memadai. Dengan demikian, fenomena yang ada dikaji secara kurang mendalam, dan menghasilkan solusi yang dinilai masih kurang tepat sasaran dan minim analisis untuk pengaplikasiannya.

- Lingkup wilayah, turut membatasi lingkup pengkajian yang hanya melihat kondisi lalu lintas di ruas jalan yang menjadi objek observasi. Pada kenyatannya, bisa jadi terdapat interaksi dengan kawasan sekitarnya yang mungkin saja memengaruhi permasalahan pergerakan yang terjadi di ruas ini. 


\section{DAFTAR PUSTAKA}

Aditiyananta. (2014). “Fenomena tata Guna Lahan, Perumahan dan Transportasi dalam Pengembangan Kota-kota Besar, Kasus Kota Surabaya dan Metropolitan GKS Plus “. Jurnal Planesa Vol.05 No.01 Mei 2014 36-44

Fisu AA. (2016). “ Analisis dan Konsep Perencanaan Kawasan Pelabuhan Kota Penajam sebagai Pintu Gerbang kab. Penajam Paser Utara, Kalimantan Timur”. Jurnal Pena Teknik Vol.01 No.02 September 2016. 125-136.

Fisu AA. (2018). "Analisis Kebutuhan Fasilitas Sisi Laut Pelabuhan Terminal Khusus PLTGU Lombok”. Jurnal Pena Teknik Vol.03 No.02 2018. 197-206

Fisu AA. (2018). “Analisis Lokasi Pada Perencanaan Terminal Topoyo, Mamuju Tengah". Jurnal Pena Teknik Vol.02 No.01 2018

Fisu AA. (2016). "Potensi Demand pengembangan Kanal Jongaya \& Panampu Sebagai Moda Transportasi Kota Makassar". Jurnal JMTranslog Trisakti Vol 03 no 03, Jakarta.

Fisu AA. (2019). Analisis Kelayakan Ekonomi \& Finansial pada Masterplan Kawasan Industri Perikanan Kota Tarakan. https://doi.org/10.31227/osf.io/96yzu

Hukmia. (2015). " Pengaruh Aktifitas Komersial Terhadap lalu Lintas di Koridor Jalan Perintis Kemerdekaan “. Jurnal Perencanaan Wilayah Kota Plano Madani Vol.05 No.02 79-90

Humang Windra Priatna \& Zulfadly, (2016), "Analisis Keterpaduan Moda Transportasi Angkutan Penyeberangan Dengan Jalan Raya di Pelabuhan Bajoe Kab. Bone”, Jurnal Pena Teknik Universitas Andi Djemma, Palopo

Katiandagho MY. Ngangi CR. Kaunang R. (2017). “ Analisis Konflik Pemanfaatan Ruang Pada jalur Transportasi di Kawasan Kota Manado “. Jurnal Berkala Ilmiah Efisiensi Vol.17 No.02 2017 72-83.

Wardhana IW \& Haryanto R. (2016). “ Kajian Pemanfaatan Ruang Kegiatan Komersial Kooridor Jalan Taman Siswa Kota Semarang “. Jurnal Pengembangan Kota Vol.04 No.01 2016 49-57. 